B. І. Кажан

канд. філол. наук, доцент

Р. П. Калініна

канд. філол. наук, доцент

\title{
ЗАСОБИ АКТУАЛІЗАЦІЇ ВИРАЖАЛЬНО-ЕКСПРЕСИВНИХ МОЖЛИВОСТЕЙ ГАЗЕТНИХ ЗАГОЛОВКІВ
}

Вивчення мовних особливостей газет засвідчує посилення емоційно-оцінної функиії газетних заголовків завдяки оригінальним синтаксичним конструкиіям, залучення арсеналу лексико-фразеологічних засобів та стилістичних прийомів.

Заголовок розглядається дослідниками як «абревіатура змісту» [2, 167] всього тексту, як засіб актуалізації газетного мовлення взагалі.

Вивчення мовних особливостей газет «Коментар», «Дзеркало тижня», «Критика», «Україна молода» засвідчує посилення емоційно-оцінної функції газетних заголовків завдяки оригінальним синтаксичним конструкціям, залучення арсеналу лексико-фразеологічних засобів та стилістичних прийомів.

До експресивних конструкцій, які останнім часом відновили свою активність, належать:

1. Питальні та риторичні конструкції типу: Коли українещь не є українщем? У боротьбі з бідністю перемагає... бідність? Які паспортини засунути в штанини? Після иінової «епідемї» виживуть тільки тролейбуси? Пам'ять про свободу? 
2. Конструкції, що за формою є видозміненими прислів'ями, крилатими висловами: На Нилі посуха, а в Києві князь; Прокрустів пояс (трансформований фразеологізм «прокрустове ложе»; у тексті - «пояс дружби» - йдеться про країни СНД, які межують з Росією і створюють так званий «пояс дружби»); Буриданів віслюк України (про політику влади до виборів).

3. Конструкції, які виявляють асоціативно-змістовий зв'язок із пісенними та літературно-художніми рядками, з назвами літературних творів та кінофільмів: Це солодке слово помаранчевий; Острів невезення, або кому дістанеться; Червоне і чорне; Толстой як дзеркало украӥнського правопису; Вечори на хуторі Михайлівському; Білорусь - Росія; холодна зима 2004го; Наше місиеве Ватерлоо; Соціальні мережі: місие зустрічі змінити не можна; «Гіперболоїд» прокурора Гаріної; П’яте «Колесо» до міста (театр I. Кліщевської програв «квартирне питання»).

4. Конструкції, побудовані на основі видозміни назв відомих телепрограм: «Велике прання» української політики; Криве дзеркало української душі; Післямова до прелюдії; «СВ»-шоу (про газету «Сільські вісті»).

Зупинимося детальніше на дієвих лексичних засобах створення мовної експресії і актуалізації газетних заголовків.

Особливе стилістичне забарвлення притаманне неологізмам. Творяться нові слова переважно за допомогою префіксації та основоскладання. Наведемо приклади: Розколективізачія історії; Перенедоперемогли; Відкриті та квазівідкриті; Перекусимо грантоїдами; Справа вірменозбереження; I післядемократія; Карпатоманія; Харківські МЕТРОморфози; Ще трохи і просочимося (від СОТ - Світова Організація Торгівлі). Експресія новизни викликана незвичайністю назви, яка дається соціальній реалії.

Розвиток внутрішніх зв'язків слів та переосмислення значень наявних у мові слів веде до виникнення семантичних неологізмів. На основі прямого значення слова можуть утворитися декілька семантичних неологізмів (наприклад, лексема «прозорий» має два переносні значення: «приємний для слуху; мелодійний, чистий» і «доступний для сприймання; дохідливий; неприхований; явний». У заголовку «Прозорі вибори» - «неприховані, щиpi, відверті»).

Газетні тексти не можуть обійтися без термінів, професіоналізмів, номенклатурно-термінологічних найменувань. Це випливає з самого призначення газети - оперативно реагувати на найважливіші події поточного моменту в різних сферах життя.

Спостереження довели, що в заголовках переважає загальнозрозуміла термінологічна лексика різних галузей знань, наприклад: Bid авторитаризму до олігархократії; Ірак як прецедент; 10 років після геноциду.

Останнім часом поширилися випадки функціонування в газетних заголовках вузькоспеціальних термінів. Наведемо приклади: Революиія $i$ вiльний фендом (неформальна профспілка письменників-фантастів); Інформель (стиль неформального мистецтва). 
Терміни в мові газетної публіцистики можуть розвивати переносне значення, тобто набувати здатності до детермінологізації. Так, медичний термін «синдром» («комплекс характерних для певного захворювання симптомів») у заголовку «Румунський синдром» набув значення: «негативні ознаки якогось явища».

Детермінологізація може відбуватися і внаслідок узагальнення спеціального поняття. Наприклад, технічний термін «технологія» (сукупність способів обробки чи переробки металів) у заголовку «Політичні технолоziï» використовується в узагальненому значенні «спосіб поетапного впровадження ідей в життя».

Отже, у процесі функціонування терміни, втрачаючи однозначність, набувають експресивної значущості і нових відтінків значення.

Для вказаних періодичних видань притаманним є пошук влучних оцінок явищ, подій, які вимагають незвичних лексичних сполучень слів різної предметно-понятійної співвіднесеності. Заголовки з такими сполученнями завжди привертають до себе увагу. Наприклад: Цінова «епідемія»; Донорські підпірки для саркофагу; Бумеранг політобіиянок; Податкові головлі; Бермуди Євразії в дискурсі чуми; Руда на виріст.

Зазначимо, що експресивним центром у подібних сполученнях є слово, естетично-переосмислене і використане незвичним (оказіональним) способом.

Унаслідок оказіональної сполучуваності слів можуть формуватися метафори, які є потужним засобом підсилення виразних властивостей заголовків. Наприклад: Анатомія душі майдану; Ожиріння бюджету (за допомогою метафор наголошується на нетиповості соціально-політичних процесів у країні). Як бачимо, метафори тематично пов'язані з центральними поняттями сучасної політичної ситуації і служать вираженням соціальної оцінки. «Оцінність виступає як головний, визначальний фактор метафоризації у публіцистиці», - підкреслює Г. Я. Солганик $[3,76]$.

Експресивна сила метафор може підсилюватися завдяки виразним епітетам: Мовчазна війна топонімів; Незаконослухняна мова; Бюро високого польоту (МВС ініціює створення Національного антикорупційного бюро).

Досить часто журналісти послуговуються дієслівними метафорамиуособленнями, які активізують увагу читача до змісту повідомлюваного, наприклад: Банкомати переводять подих; Фондові індекси мерзнуть; Залізо стомилося, люди - теж (про ліквідацію артбази під Новобогданівкою).

Інколи в ролі заголовків виступає перифраз, який у формі словосполучення передає назву предмета, виділяючи в ньому найсуттєвішу з позиції автора рису. Наприклад: Пес демократії мусить бути голодним (йдеться про пресу); Свропейські контракти стиглих помаранчів (українські письменники, твори яких видані за кордоном); Де поділася весна народу? 
(програми ліберальних рухів і революцій, відомі під назвою «Весна Народів»). У заголовку, як бачимо, перифраз виступає як переносно-образний еквівалент окремого слова (преса, письменники, програми).

Велике емоційно-експресивне навантаження в публіцистичному мовленні несе оксюморон, контрастне зіткнення двох логічно несумісних понять, наприклад: Ціна привабливого зла; Приватні розмови з безмовним; Присмерк майбутнього; Час нещасних щасливців; Переваги противаг; Злочин і зразково показове покарання.

Експресія газетних заголовків може підсилюватися завдяки антонімічним засобам. Для зіставлення протилежних реалій дійсності журналісти послуговуються як загальномовними, так і контекстуальними антонімічними парами. Наприклад: Загадки та відгадки лукашенківщини; Вибори у США: очевидна перемога і неочевидне майбутнє; Мала енциклопедія великого україния; Майдани $і$ кабінети; Eпоха реставрації $і$ епоха стагнації (застій у виробництві).

Фіксуємо в заголовках і альтернативне запитання, яке передбачає вибір між двома можливостями, що виключають одна одну $[1,46]$. Наведемо приклади: Подвиг чи провокація? Технологічна кампанія, технічний нокаym? Eфір: ресурс чи годівниия? Ви депутати чи аморальні? (про заклик президента до ВР відмовитися від зимових канікул).

Приховану антонімічність спостерігаємо в заголовках, створених за допомогою такого образного засобу, як іронія: Між братньою Росією та мирною Європою; Криве дзеркало прямого ефіру; Украӥна і Росія: сімейна любовість.

3 метою залучення уваги читача автори публікацій, шукаючи незвичних експресивних прийомів, нерідко підключають мовну гру, яка $є$ свідомим порушенням норми. Наведемо приклади: справжній харків'янин (нів) року; Чому я не за Я; Юристи - в законі, фізики - в загоні; Наме коло на «коло нас»; Не наша, не єдина. Літературна; Екс-прем'єр-опозЗиіонер; Київ завМЕР (про дострокові вибори міського голови); БЮТ розродився «ДеБЮТом» (закарпатські БЮТівці запровадили літературну премію під оригінальною назвою «ДеБЮТ»).

У мовній грі, як бачимо, обіграванню підлягають синоніми, антоніми, пароніми, неспоріднені співзвучні слова.

Особливу виразність заголовкам надає повтор багатозначного слова, яке має інше значення, наприклад: Майстри на майстер-класі; Чисте місто - чиста совість! Чисте місто - чисті руки!

Отже, з метою активізації читацької уваги публіцисти послуговуються потужними зображально-виражальними й експресивними засобами різних рівнів.

Сутність мовної експресії в газетних заголовках полягає в подоланні стандарту у використанні синтаксичних конструкцій та лексикофразеологічних одиниць. 


\section{Список використаної літератури}

1. Коваль А. П. Практична стилістика сучасної української літературної мови. К.: Вища школа, 1987. - 351 с.

2. Николина Н. А. Филологический анализ текста. - М.: Академия, 2003. - 256 с.

3. Солганик Г. Я. Лексика газеты. - М.: Высш. шк., 1981. - 112 с.

\section{Summary}

Studing of language pacularities of newspapers shows the increasing of emotive evaluation of newspaper's head-lines due to specific syntactic constructions, due to usage of big quantity of lexico-phraseological devices and stylistic means. 